\title{
PENGARUH MODEL PEMBELAJARAN KOOPERATIF TIPE TWO STAY TWO STRAY (TS-TS) TERHADAP KEMAMPUAN PEMECAHAN MASALAH MATEMATIKA SISWA KELAS XI IPA SMA NEGERI 1 SELESAI TAHUN PELAJARAN 2019/2020
}

\author{
Silvia Harleni ${ }^{1}$ \\ STKIP Budidaya \\ syl_nst@yahoo.com ${ }^{1}$
}

\begin{abstract}
ABSTRAK
Tujuan penelitian ini untuk mengetahui pengaruh model pembelajaran kooperatif tipe Two Stay Two Stray (TS-TS) terhadap kemampuan pemecahan masalah siswa. Penelitian ini merupakan penelitian eksperimen semu, dengan desain penelitian pre-test and post-test control group design. Populasi dalam penelitian ini adalah seluruh siswa kelas XI IPA Negeri 1 Selesai Tahun Pelajaran 2019/2020, sedangkan sampel dalam penelitian ini adalah kelas XI IPA 3 yang berjumlah 32 siswa sebagai kelas eksperimen dan kelas XI IPA 4 yang berjumlah 30 siswa sebagai kelas kontol. Berdasarkan hasil penelitian mengungkapkan bahwa model pembelajaran kooperatif tipe Two Stay Two Stray (TS-TS) berpengaruh terhadap kemampuan pemecahan masalah siswa. Hal ini dapat dilihat dari nilai rata-rata kelas eksperimen adalah sebesar 73,63 dan nilai rata-rata kelas kontrol adalah sebesar 50,23. Terdapat pengaruh yang signifikan antara pembelajaran kooperatif tipe Two Stay Two Stray (TS-TS) terhadap pemahaman konsep matematika siswa yang dapat dilihat dari hasil perhitungan analisis data yang menggunakan uji-t dengan nilai $t_{\text {hitung }}>t_{\text {tabel }}(4,499>1,671)$ dengan derajat kebebasan $(\mathrm{db})=60$, dengan taraf signifikan 0,05. Dengan demikian $\mathrm{H}_{\mathrm{o}}$ ditolak dan $\mathrm{H}_{\mathrm{a}}$ diterima, yang artinya rata-rata kemampuan pemecahan masalah siswa pada kelas eksperimen lebih besar dari rata-rata kemampuan pemecahan masalah siswa pada kelas kontrol. Hal ini berarti terdapat pengaruh penggunaan model pembelajaran kooperatif tipe tipe Two Stay Two Stray (TSTS) terhadap kemampuan pemecahan masalah siswa di kelas XI IPA SMA Negeri 1 Selesai Tahun Pelajaran 2019/2020.
\end{abstract}

Kata Kunci : Model Pembelajaran Model Pembelajaran Kooperatif tipe Two Stay Two Stray (TSTS), Kemampuan Pemecahan Masalah.

\section{PENDAHULUAN}

Matematika adalah ilmu yang membahas pola atau keteraturan. Karena matematika merupakan ilmu yang universal yang mendasari perkembangan teknologi modern yang mempunyai peran penting dalam berbagai disiplin dan memajukan daya pikir manusia, perkembangan dibidang IPTEK dilandasi oleh perkembangan matematika dibidang teori bilangan, aljabar, analisis, teori peluang dan matematika diskrit. Perkembangan pendidikan matematika haruslah sejalan dengan kebutuhan masyarakat yang semakin berkembang. Meidawati (2014) menyatakan bahwa matematika merupakan pengetahuan yang esensial sebagai dasar untuk bekerja untuk 
mendapatkan pekerjaan yang layak karena abad globalisasi, seumur hidup dalam abad globalisasi. Karena itu penguasaan tingkat tertentu terhadap matematika diperlukan bagi semua siswa agar kelak dalam hidupnya memungkinkan tiada pekerjaan tanpa matematika.

Faktor yang dapat menunjang keberhasilan siswa dalam pelajaran matematika tidak hanya dari kemampuan siswa sendiri namun didukung oleh faktor guru dan juga model pembelajaran yang digunakan di dalam kelas. Menurut Fatmawati, dkk (2014) menyatakan bahwa yang harus dipelajari siswa, yaitu memahami masalah, merancang model matematika, menyelesaikan model, dan menafsirkan solusi yang diperoleh.

Kemampuan pemecahan masalah merupakan hal yang sangat penting. Penelitian tentang pemecahan masalah telah banyak dilakukan, salah satunya penelitian dari Harleni dan Susilawati (2018) yang berjudul "Efektivitas Penggunaan Model Problem Based Learning Terhadap Kemampuan Pemecahan Masalah Program Linier Dengan Memanfaatkan Software QM Pada Mahasiswa STKIP Budidaya Binjai”. Harleni (2019) juga melakukan penelitian tentang pengaruh pendekatan matematika realistik terhadap kemampuan pemecahan masalah matematika siswa. Susanto (2013) juga mengemukakan bahwa pemecahan masalah sebagai strategi pembelajaran adalah suatu teknik dimana masalah digunakan secara langsung sebagai alat untuk membantu siswa memahami materi pelajaran yang sedang mereka pelajar. Siswa tidak akan tertarik untuk belajar memecahkan masalah, jika siswa tidak tertantang untuk mengerjakannya. NCSM (National Council of supervisor Mathematics) menyatakan belajar menyelesaikan masalah adalah alasan utama untuk mempelajari matematika, dengan kata lain pemecahan masalah merupakan sumbu dari proses-proses matematika. Pemecahan masalah bukan hanya sebagai tujuan dari belajar matematika akan tetapi merupakan alat utama untuk melakukannya. Pembelajaran matematika memfokuskan bahwa tujuan pembelajaran matematika adalah untuk melatih cara berpikir dan bernalar, mengembangkan kemampuan pemecahan masalah, dan mengembangkan kemampuan berkomunikasi. Jadi, siswa dapat dikatakan tuntas jika ketiga aspek tersebut terpenuhi. Akan tetapi, pada kenyataanya siswa masih mengalami kesulitan untuk memenuhi ketiga aspek di atas, terutama aspek pemecahan masalah. Selama ini, siswa hanya bermodal menghafal rumus untuk menyelesaikan soal-soal matematika, sehingga soal-soal yang diberikan oleh guru yang mengacu pada aspek pemecahan masalah kurang dapat diselesaikan siswa dengan baik, maka bisa berdampak pada rendahnya nilai ujian semester matematika. Pemerintah juga memandang bahwa kemampuan pemecahan masalah dalam pembelajaran matematika itu penting. Purwosusilo (2014) juga mengemukakan bahwa strategi pemecahan masalah yang meliputi 4 tahap utama dengan sejumlah langkah pendukung yaitu: (1) mengerti masalah, meliputi: apa yang ditanyakan atau dibuktikan, data apa yang diketahui, dan bagaimana syarat-syaratnya; (2) merencanakan penyelesaian, meliputi: pengumpulan informasi yang berkaitan persyaratan yang telah ditentukan, menganalisis informasi dengan menggunakan analogi masalah, dan jika siswa menemui jalan buntu, guru membantu mereka melihat masalah dari sudut yang berbeda; (3) melaksanakan penyelesaian, dan; (4) melihat kembali, dengan maksud untuk mengetahui kecocokan hasil, apakah ada hasil yang lain, apakah ada cara lain untuk menyelesaikan masalah tersebut, dan dengan cara yang berbeda apakah hasilnya sama.

Siswa menganggap bahwa materi sistem persamaan linear dua variabel sulit dipelajari. Apalagi dalam menyelesaikan materi sistem persamaan linear dua variabel. Hal ini didukung oleh hasil wawancara dengan salah seorang guru matematika SMA Negeri 1 
Selesai menyatakan bahwa banyak siswa yang mengalami kesulitan dalam menyelesaikan soal sistem persamaan linear variabel dalam bentuk cerita.

Pemecahan masalah merupakan suatu cara atau metode untuk menemukan suatu alternatif jalan keluar suatu masalah. Keseharian atau situasi-situasi pembuatan keputusan. Dengan demikian kemampuan pemecahan masalah membantu siswa secara baik dalam pembelajaran dan kehidupan seharihari. Salah satu kemampuan pemecahan masalah siswa dalam hal penelitian ini adalah penalaran induktif, antara lain dengan menggunakan model pembelajaran kooperatif karena lebih mengutamakan keaktifan siswa dan guru hanya sebagai fasilisator sehingga siswa lebih bebas untuk mengemukakan ide kreatifnya sendiri dengan berdiskusi antar teman dan suasana menjadi lebih hidup. Pembelajaran yang sebaiknya digunakan yaitu dengan pembelajaran berkelompok/kooperatif.

Dalam pembelajaran kooperatif, siswa diberi kebebasan untuk mengkonstruksi pengetahuannya, mengkoordinasikan ide-ide yang dimilikinya. Salah satu model pembelajaran kooperatif yang sesuai adalah model pembelajaran kooperatif tipe Two Stay Two Stray (TS-TS). Menurut Miftachudin, dkk (2015) bahwa model pembelajaran kooperatif tipe Two Stay Two Stray (dua tinggal dua tamu) dapat digunakan dalam semua pelajaran dan untuk semua tingkatan usia peserta didik. Model pembelajaran Two Stay Two Stray ini dapat membuat peserta didik aktif dalam pembelajaran, selain itu model ini memberi kesempatan untuk bekerja sendiri serta bekerja sama dengan orang lain. Keunggulan lain dari model ini adalah optimalisasi partisipasi siswa, sehingga siswa dapat berdiskusi dengan temannya, tentu saja hal ini dapat meningkatkan minat siswa dalam belajar.

Model pembelajaran kooperatif tipe Two Stay Two Stray tidak sama dengan sekedar belajar dalam kelompok. Ada unsurunsur dasar model pembelajaran kooperatif yang membedakannya dengan pembagian kelompok. Ciri khas dari model pembelajaran ini adalah adanya pembagian tugas dari dalam kelompok, ada yang bertugas sebagai tamu untuk mencari informasi dari kelompok lain dan ada yang bertugas sebagai penerima tamu yang bertugas memberikan informasi atau hasil diskusi kelompoknya. Sehingga setiap peserta didik dilatih untuk mengungkapkan idenya dalam menyelsaikan persoalan yang diberikan oleh guru. Pelaksanaan prosedur model pembelajaran kooperatif tipe Two Stay Two Stray dengan benar akan memungkinkan pendidik mengelola kelas dengan lebih efektif. Dalam pembelajaran kooperatif, siswa belajar dalam kelompok kecil untuk mencapai tujuan yang sama menggunakan kemampuan sosial.

Dalam suatu kegiatan pembelajaran, keterlibatan siswa secara aktif mutlak diperlukan, karena inti dari proses belajar mengajar adalah siswa belajar. Berdasarkan uraian di atas, maka penulis tertarik melakukan penelitian tentang: "Pengaruh Model Pembelajaran Kooperatif Tipe Two Stay Two Stray (TS-TS) Terhadap Kemampuan Pemecahan Masalah Matematika Siswa Kelas XI IPA SMA Negeri 1 Selesai Tahun Pelajaran 2019/2020”.

\section{METODE PENELITIAN}

Lokasi penelitian ini di SMA Negeri 1 Selesai, Jl. Binjai-Selayang Simpang Selesai, Padang Brahrang. Teknik sampling yang digunakan adalah Simple Random Sampling. Sampel yang digunakan dalam penelitian ini adalah dua kelas dimana nama yang keluar pertama sebagai kelas eksperimen yaitu kelas XI IPA 3 yang berjumlah 32 siswa. Setelah itu pengundian kedua nama yang keluar sebagai kelas kontrol yaitu kelas XI IPA 4 yang berjumlah 30 siswa. Dengan demikian sampel keseluruhan berjumlah 62 siswa.

Jenis penelitian yang digunakan dalam penelitian ini adalah eksperimen semu (quasi experimental). Perlakuan yang diberikan yaitu pembelajaran matematika dengan 
menggunakan model pembelajaran kooperatif tipe Two Stay Two Stray (TS-TS) pada kelas eksperimen dan model pembelajaran konvensional pada kelas kontrol. Penelitian dilakukan untuk melihat pengaruh model pembelajaran kooperatif tipe Two Stay Two Stray (TS-TS) terhadap kemampuan pemecahan masalah matematika siswa kelas XI IPA SMA Negeri 1 Selesai.

Desain penelitian yang digunakan pada penelitian ini adalah Pretest-Posttest Control Group Design. Variabel bebas dalam penelitian ini adalah model pembelajaran kooperatif tipe Two Stay Two Stray (TS-TS). Variabel terikat dalam penelitian ini adalah kemampuan pemecahan masalah matematika siswa. Tes yang digunakan dalam penelitian ini adalah tes subjektif yang berbentuk essay sebanyak 4 butir soal. Teknik analisis data yang digunakan adalah uji sistematik.

\section{HASIL PENELITIAN DAN PEMBAHASAN}

\section{A. Deskripsi Data}

Penelitian mengenai kemampuan pemecahan masalah matematika siswa ini dilakukan di SMA Negeri 1 Selesai. Populasi dalam penelitian ini adalah seluruh siswa kelas XI IPA SMA Negeri 1 Selesai yang terdiri dari empat kelas. Setelah peneliti menentukan populasi, langkah selanjutnya yaitu pemilihan sampel dengan menggunakan teknik Simple Random Sampling (acak). Dari proses acak terhadap empat kelas yang ada, diproleh sampel yaitu kelas XI IPA 3 yang berjumlah 32 siswa sebagai kelas eksperimen yang diajarkan dengan menggunakan model pembelajaran kooperatif tipe Two Stay Two Stray (TS-TS) dan kelas XI IPA 4 yang berjumlah 30 siswa sebagai kelas kontrol dengan model pembelajaran konvensional. Metode konvensional yang dimaksud adalah pembelajaran yang biasa diterapkan di SMA Negeri 1 Selesai, seperti model pembelajaran ceramah, diskusi kelompok, tanya jawab, dan penugasan.

Sebelum melakukan penelitian, peneliti terlebih dahulu membuat instrumen tes untuk mengukur kemampuan pemecahan masalah matematika siswa yang nantinya akan diberikan kepada kedua kelas. Instrumen tes ini terdiri dari empat soal uraian. Setelah melakukan instrumen, selanjutnya dilakukan uji validitas, uji reliabilitas, uji tarif kesukaran butir soal dan uji daya pembeda pada setiap butir soalnya. Berikut ini akan disajikan hasil pretest dan posttest pada kedua kelas tersebut yaitu kelas eksperiment dan kelas kontrol.

\section{Data Hasil Pretest Kemampuan Pemecahan Masalah Matematika Siswa Kelas Eksperimen Dan Kelas Kontrol}

Sebelum melaksanakan pembelajaran pada kedua kelas dengan model pembelajaran yang berbeda yakni dengan model pembelajaran kooperatif Two Stay Two Stray (TS-TS) pada kelas eksperimen dan model pembelajaran konvensional pada kelas kontrol. Data hasil pretest yang diberikan kepada kelas eksperimen berjumlah 32 siswa dan kelas kontrol berjumlah 30 siswa. Untuk lebih jelasnya, data hasil tes kemampuan pemecahan masalah matematika siswa kelas eksperimen dan kelas kontrol disajikan dalam tabel statistik deskriptif berikut:

Tabel 1. Statistik Deskriptif Pretest Kelas Eksperimen Dan Kelas Kontrol

\begin{tabular}{|c|c|c|c|}
\hline \multirow[b]{2}{*}{ No } & \multirow[b]{2}{*}{$\begin{array}{l}\text { Ukuran } \\
\text { Statistik }\end{array}$} & \multicolumn{2}{|c|}{ Pretest } \\
\hline & & $\begin{array}{c}\text { Kelas } \\
\text { Eksperim } \\
\text { ent }\end{array}$ & $\begin{array}{c}\text { Kelas } \\
\text { Kontro } \\
\text { l }\end{array}$ \\
\hline 1 & Jumlah siswa & 32 & 30 \\
\hline 2 & Jumlah nilai & 915,4 & 956,3 \\
\hline 3 & $\begin{array}{l}\text { Nilai } \\
\text { maksimum }\end{array}$ & 66,6 & 66,6 \\
\hline 4 & Nilai minimum & 8,3 & 8,3 \\
\hline 5 & Rata-rata & 28.60 & 31,87 \\
\hline 6 & Simpangan & 16,92 & 17,67 \\
\hline
\end{tabular}




\begin{tabular}{lrrr}
\hline \multicolumn{3}{c}{ baku } & \\
\hline 7 & Varians & 286,61 & 312,49 \\
\hline
\end{tabular}

Pada tabel di atas terlihat bahwa hasil perhitungan pretest pada kelas eksperimen diperoleh nilai varians 286,61 dan simpangan baku 16,92. Sedangkan pada kelas kontrol diperoleh nilai varians 312,49 dan simpangan bakunya yaitu 17,67 . Hasil pemberian pretest diperoleh nilai rata-rata dikelas eksperimen 28,60 dan hasil pemberian nilai pretest pada kelas kontrol diperoleh nilai rata-rata 31,87. Perbedaan nilai rata-rata siswa antara kelas eksperimen dengan kelas kontrol menunjukkan homogen yang berarti kemampuan awal siswa sama. Hal ini juga dibuktikan dengan uji t pada lampiran 35 yaitu diperoleh $t_{\text {hitung }}=-0,743$ dan $t_{\text {tabel }}=1,671$. Karena $\mathrm{t}_{\text {hitung }}<\mathrm{t}_{\text {tabel }}$ yaitu $-0,743<1,671$ maka $\mathrm{H}_{\mathrm{o}}$ diterima dan $\mathrm{H}_{\mathrm{a}}$ ditolak maka disimpulkan tidak terdapat perbedaan kemampuan awal antara siswa kelas eksperimen dengan kelas kontrol.

Secara visual penyebaran data kemampuan pemahaman konsep matematika siswa kelas eksperimen yang menggunakan model pembelajaran Two Stay Two Stray (TSTS) dan kelas kontrol yang menggunakan metode pembelajaran konvensional dapat dilihat pada histogram perbedaan nilai ratarata, simpangan baku, dan varians pretest kelas eksperimen dan kelas kontrol sebagai berikut:

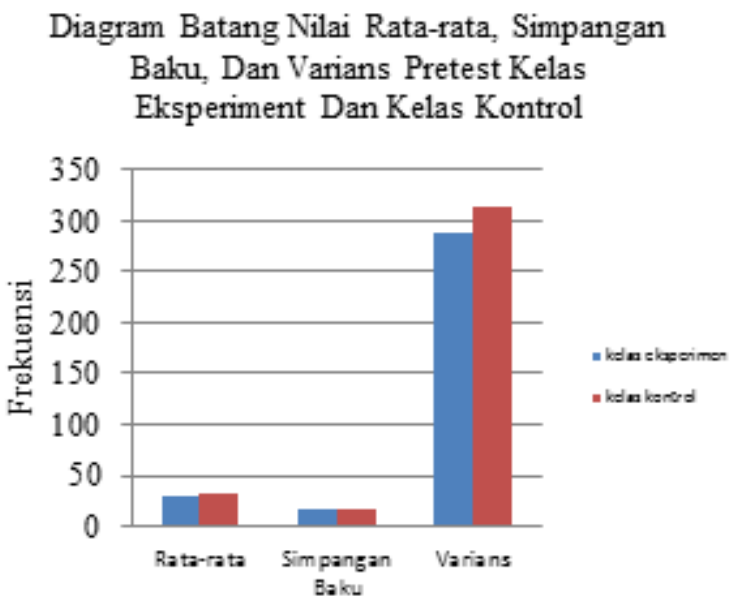

Gambar 3. Perbedaan Rata-Rata, Simpang

Baku, Dan Varians Pretest Eksperiment Dan Kelas Kontrol

2. Data Posttest Kemampuan Pemahaman Konsep Matematika Siswa Kelas Eksperimen Dan Kelas Kontrol

Setelah diberikan pretest pada kedua kelas dan diperoleh tidak ada perbedaan kemampuan awal siswa, maka dilakukan pembelajaran yang berbeda yaitu di kelas eksperimen dengan model pembelajaran Two Stay Two Stray (TSTS) dan di kelas kontrol dengan metode pembelajaran konvensional. Untuk lebih jelasnya, data hasil tes kemampuan pemecahan masalah matematika siswa kelas eksperimen dan kelas kontrol disajikan dalam tabel statistik deskriptif berikut:

Tabel 2. Statistik Deskriptif Posttest Kelas Eksperimen Dan Kelas Kontrol

\begin{tabular}{|c|c|c|c|}
\hline \multirow[b]{2}{*}{ No } & \multirow[b]{2}{*}{ Ukuran Statistik } & \multicolumn{2}{|c|}{ Posttest } \\
\hline & & $\begin{array}{c}\text { Kelas } \\
\text { Eksper } \\
\text { iment }\end{array}$ & $\begin{array}{c}\text { Kelas } \\
\text { Kontr } \\
\text { ol }\end{array}$ \\
\hline 1 & Jumlah siswa & 32 & 30 \\
\hline 2 & Jumlah nilai & 2356,4 & 1507 \\
\hline 3 & Nilai maksimum & 100 & 75 \\
\hline 4 & Nilai minimum & 33,3 & 16,6 \\
\hline 5 & Rata-rata & 73,63 & 50,23 \\
\hline 6 & Simpangan baku & 17,81 & 19,54 \\
\hline 7 & Varians & 317,54 & 382,03 \\
\hline $\begin{array}{l}\text { perhit } \\
\text { diper } \\
\text { bakun } \\
\text { kontr } \\
\text { simpa } \\
\text { pemb } \\
\text { dikela } \\
\text { Postte } \\
\text { Perbe } \\
\text { ekspe } \\
\text { homo }\end{array}$ & $\begin{array}{l}\text { da tabel di atas te } \\
\text { ngan Posttest pad } \\
\text { eh nilai varians } 317 \\
\text { a yaitu 17,81. Sed } \\
\text { diperoleh nilai } \\
\text { gan bakunya ya } \\
\text { rian Posttest diper } \\
\text { eksperimen } 73,63 \\
t \text { diperoleh nila } \\
\text { aan nilai rata-rata } \\
\text { men dengan kelas k } \\
\text { en yang berarti kmk } \\
\text { i juga dibuktikan }\end{array}$ & $\begin{array}{l}\text { rlihat bah } \\
\text { kelas ek } \\
54 \text { dan } \mathrm{s} \\
\text { angkan p } \\
\text { arians } 38 \\
\text { tu } 19,5 \\
\text { leh nilai } \\
\text { an hasil } \mathrm{p} \\
\text { r rata-rat } \\
\text { siswa ant } \\
\text { ntrol men } \\
\text { ampuan a }\end{array}$ & $\begin{array}{l}\text { wa hasil } \\
\text { sperimen } \\
\text { mpangan } \\
\text { da kelas } \\
\text {,03 dan } \\
\text { Hasil } \\
\text { rata-rata } \\
\text { emberian } \\
50,23 . \\
\text { ra kelas } \\
\text { unjukkan } \\
\text { al sama. }\end{array}$ \\
\hline
\end{tabular}


lampiran 35 yaitu diperoleh $t_{\text {hitung }}=4,944$ dan $t_{\text {tabel }}=1,671$. Karena $t_{\text {hitung }}>t_{\text {tabel }}$ yaitu 4,944 > 1,671 maka $\mathrm{H}_{\mathrm{o}}$ ditolak dan $\mathrm{H}_{\mathrm{a}}$ diterima maka disimpulkan terdapat perbedaan kemampuan antara siswa kelas eksperimen dengan kelas kontrol setelah diberikan perlakuan. Secara visual penyebaran data kemampuan pemecahan masalah matematika siswa kelas eksperimen yang menggunakan model pembelajaran Two Stay Two Stray (TS-TS) dan metode pembelajaran konvensional di kelas kontrol dapat dilihat pada histogram perbedaan nilai rata-rata, simpangan baku, dan varians posttest kelas eksperimen dan kelas kontrol sebagai berikut.

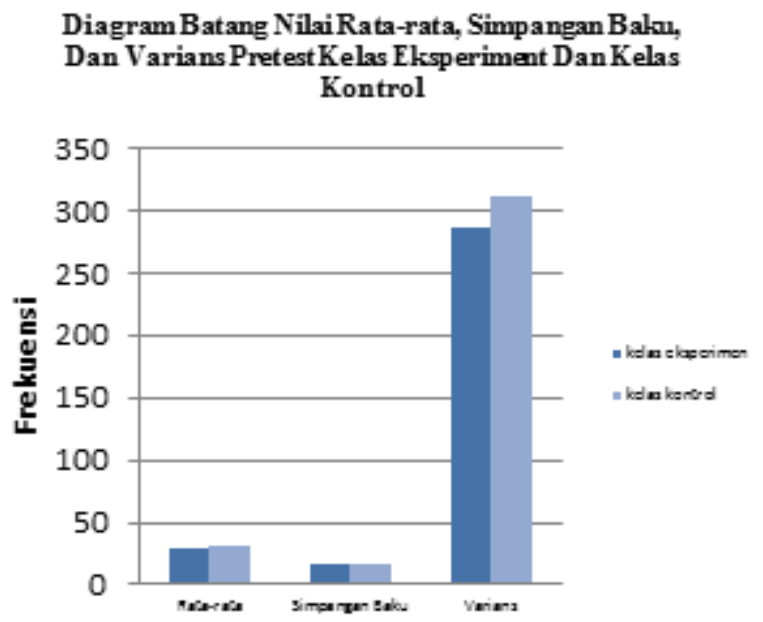

Gambar 4. Perbedaan Rata-Rata, Simpang Baku, Dan Varians Pretest Eksperiment Dan Kelas Kontrol

\section{Analisis Data}

Berdasarkan persyaratan analisis, maka sebelum dilakukan pengujian hipotesis, terlebih dahulu dilakukan uji prasyarat analisis terlebih dahulu terhadap data hasil penelitian. Uji prasyarat yang perlu dipenuhio yaitu berupa iji normalitas dan uji homogenitas. Hasil uji prasyarat analisis hingga pengujian hipotesis akan dipaparkan sebagai berikut:
Uji normalitas yang digunakan adalah uji Liliefors. Uji Liliefors digunakan untuk mengetahui apakah data berasal dari populasi yang berdistribusi normal atau tidak, dengan ketentuan bahwa data berasal dari populasi yang berdistribusi normal jika memenuhi kriteria $\mathrm{L}_{\mathrm{o}}<\mathrm{L}_{\mathrm{t}}$ diukur pada taraf signifikasi dan tingkat kepercayaan tertentu. Hipotesis yang diajukan dan akan diuji dalam uji normalitas ini sebagai berikut:

$\mathrm{H}_{\mathrm{o}}$ : data sampel berasal dari populasi yang berdistribusi normal

$\mathrm{H}_{\mathrm{a}}$ : data sampel berasal dari populasi yang tidak berdistribusi normal

Berdasarkan hasil perhitungan uji normalitas pretest dapat dilihat pada tabel dibawah ini:

Tabel 3. Rekapitulasi hasil perhitungan uji normalitas pretest - posttest dengan uji liliefors

\begin{tabular}{|c|c|c|c|c|c|}
\hline $\begin{array}{l}\text { D } \\
\text { at } \\
\text { a }\end{array}$ & $\begin{array}{c}\text { kelomp } \\
\text { ok }\end{array}$ & $\mathbf{L}_{\mathbf{0}}$ & $\mathbf{L}_{\mathbf{t}}$ & $\begin{array}{c}\text { kesi } \\
\text { mpul } \\
\text { an }\end{array}$ & $\begin{array}{c}\text { ketera } \\
\text { ngan }\end{array}$ \\
\hline & $\begin{array}{l}\text { Eksperi } \\
\text { men }\end{array}$ & $\begin{array}{c}0, \\
1463\end{array}$ & $\begin{array}{c}0,156 \\
6 \\
\end{array}$ & $\begin{array}{c}\text { Terim } \\
\mathrm{a} \mathrm{H}_{\mathrm{o}}\end{array}$ & Normal \\
\hline ڤ్ & Kontrol & $\begin{array}{c}0,14 \\
03\end{array}$ & 0,161 & $\begin{array}{c}\text { Terim } \\
\mathrm{a} \mathrm{H}_{\mathrm{o}}\end{array}$ & Normal \\
\hline$\stackrel{5}{0}$ & $\begin{array}{l}\text { Eksperi } \\
\text { men }\end{array}$ & $\begin{array}{c}0,11 \\
27 \\
\end{array}$ & $\begin{array}{c}0.156 \\
6 \\
\end{array}$ & $\begin{array}{c}\text { Terim } \\
\mathrm{a} \mathrm{H}_{\mathrm{o}}\end{array}$ & Normal \\
\hline & Kontrol & $\begin{array}{c}0,11 \\
30\end{array}$ & 0,161 & $\begin{array}{c}\text { Terim } \\
\mathrm{a} \mathrm{H}_{\mathrm{o}}\end{array}$ & Normal \\
\hline
\end{tabular}

Berdasarkan tabel di atas, dapat dilihat bahwa data pretest dan posttest yang ada di kelas eksperimen dan kelas kontrol semuanya berdistribusi normal dengan $\mathrm{L}_{\text {tabel }}$ kelas eksperimen yaitu 0,1566 dan kelas kontrol yaitu 0,161 .

\section{b. Uji Homogenitas}

\section{a. Uji Normalitas}


Uji homogenitas atau uji kesamaan dua varians populasi dilakukan dengan uji fisher. Untuk kriteria pengujian data kedua sampel adalah homogen jika $F_{\text {hitung }}<\mathrm{F}_{\text {tabel }}$ pada taraf signifikan 5\%. Rekapitulasi hasil perhitungan uji homogenitas dapat dilihat pada tabel dibawah ini.

Tabel 4. Rekapitulasi hasil perhitungan uji homogenitas pretest - posttest dengan uji Fisher

Data Kelompok $\mathbf{F}_{\text {hitung }} \mathbf{F}_{\text {tabel }}$ kesimpula

$\mathbf{n}$

\begin{tabular}{|c|c|c|c|c|}
\hline \multirow{2}{*}{ 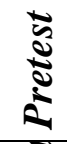 } & Eksperimen & 1,0 & \multirow[b]{2}{*}{1,84} & \multirow[b]{2}{*}{ Homogen } \\
\hline & Kontrol & 9 & & \\
\hline है & Eksperimen & 1,2 & & \\
\hline$\overline{\tilde{s}}$ & Kontrol & 0 & 1,0 & \\
\hline
\end{tabular}

Berdasarkan tabel di atas, didapat $\mathrm{F}_{\text {tabel }}$

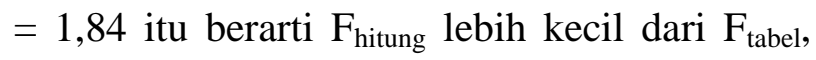
sehingga dengan demikian diperoleh keputusan uji bahwa $\mathrm{H}_{\mathrm{o}}$ diterima, hal ini menunjukkan bahwa kemampuan pemecahan masalah matematika siswa berasal dari populasi yang homogen.

\section{c. Uji kesamaan rata-rata}

Adapun hasil perhitungan kesamaan rata-rata antara kelas eksperimen dan kelas kontrol dapat dilihat pada tabel berikut :

Tabel 5. Hasil Perhitungan Kesamaan RataRata Kelas Eksperimen Dan Kelas Kontrol

\begin{tabular}{|c|c|c|c|c|}
\hline \multicolumn{3}{|c|}{ Kelompo } & \multirow[b]{2}{*}{$\mathbf{S}_{\text {gab }}$} & \multirow[b]{2}{*}{$\mathbf{t}_{\text {hitung }}$} \\
\hline $\begin{array}{l}\text { Sumber } \\
\text { varians }\end{array}$ & $\begin{array}{c}\mathbf{k} \\
\text { eksperim } \\
\text { en }\end{array}$ & $\begin{array}{l}\text { Kelompo } \\
\text { k kontrol }\end{array}$ & & \\
\hline $\mathbf{N}$ & 32 & 30 & \multirow{4}{*}{17,30} & \multirow{4}{*}{$\begin{array}{c}- \\
0,743\end{array}$} \\
\hline $\bar{X}$ & 28,60 & 31,87 & & \\
\hline $\begin{array}{c}\text { Varians } \\
\left(\mathrm{S}^{2}\right)\end{array}$ & 286,61 & 312,49 & & \\
\hline Standar & 16,92 & 17,67 & & \\
\hline
\end{tabular}

\section{Deviasi}

(S)

Berdasarkan tabel di atas, dapat diambil kesimpulan bahwa dengan taraf singniatif $\propto=0,05, d b=n_{1}+n_{2}$ maka $d b=32+30$ $2=60$, didapat $t_{\text {tabel }}=1,671$. Karena $t_{\text {hitung }}<$ $\mathrm{t}_{\text {tabel }}(-0,743<1,671)$, maka dapat disimpulkan bahwa terdapat kesamaan rata-rata antara kelas eksperimen dan kelas kontrol dengan demikian kedua yang akan digunakan sebagai sampel penelitian mempunyai kemampuan yang sama, olek karenanya kedua kelas dapat digunakan sebagai sampel penelitian.

\section{d. Pengujian hipotesis}

Telah diketahui bahwa kedua kelompok data kemampuan pemecahan masalah matematika siswa adalah berdistribusi normal dan mempunyai varians yang homogen. Dari hasil perhitungan pada lampiran 35 , diperoleh $t_{\text {hitung }}$ $=4,944$. Pada $\mathrm{dk}=60$ dan taraf nyata $\mathrm{a}=0,05$ diperoleh $t_{\text {tabel }}=1,671$, sehingga terlihat jelas bahwa $t_{\text {hitung }}>t_{\text {tabel }}$ yaitu $4,944>1,671$. Berdasarkan pengujian hipotesis $\mathrm{H}_{\mathrm{o}}$ ditolak dan $\mathrm{H}_{\mathrm{a}} \quad$ Diterima. Dengan demikian terdapat pengaruh model pembelajaran kooperatif tipe Two Stay Two Stray (TS-TS) terhadap kemampuan pemecahan masalah matematika kelas XI IPA SMA Negeri 1 Selesai Tahun Pelajaran 2019/2020.

\section{B. Pembahasan hasil penelitian}

Berdasarkan hasil tes yang telah dilakukan diperoleh nilai rata-rata kelas eksperimen ( XI IPA 3) adalah 73,63 dengan simpangan baku adalah 17,81 . Sementara nilai rata-rata kelas kontrol (XI IPA 4) 50,23 dengan simpangan baku adalah 19,54. Sehingga dari analisis data akhir (pretest) kelas eksperimen diperoleh $L_{0}=0,02888$ sedangkan $L_{t}=0,1566$. Ini menunjukkan bahwa diperoleh $L_{0}<L_{t}$ Pada uji normalitas, sementara itu analisis data akhir (posttest) kelas kontrol diperoleh $L_{0}=0,058$ sedangkan $L_{t}=0,161$ ini menunjukkan bahwa 
$L_{0}<L_{t}$ pada uji normalitas. Uji homogenitas juga menunjukkan hasil yang sama seperti uji normalitas. Jadi kesimpulanya adalah kedua kelas berasal dari kondisi yang sama.

Berdasarakan uji t-test diperoleh $t_{\text {tabel }}$ $=1,671$, sementara berdasarkan perhitungan yang telah dilakukan diperoleh $t_{\text {hitung }}=4,944$. Dari perhitungan terlihat bahwa $t_{\text {tabel }}>$ $t_{\text {hitung }}(4,944>1,671)$ maka hipotesis yang diajukan diterima. Dengan demikian, maka hasilnya dapat dikemukakan bahwa: " Terdapat pengaruh model pembelajaran Two Stay Two Stray (TS-TS) terhadap kemampuan pemecahan masalah matematika siswa pada pokok bahasan matriks kelas XI SMA Negeri 1 Selesai tahun pelajaran 2019/2020".

\section{DAFTAR PUSTAKA}

Fatmawati H., Mardiana, Triyanto, Analisis Berfikir Kritis Siswa Dalam Pemecahan Masalah Matematika Berdasarkan Polya Pada Pokok Bahasan Persamaan Kuadrat, Jurnal Elektronik Pembelajaran Matematika, vol.2(9), Srage, 2014.

Harleni S., Pengaruh Pendekatan Matematika Realistik Terhadap Kemampuan Pemecahan Masalah Matematika (PMR) Siswa Kelas VIII MTs Al Azhar Bulu Cina Tahun Pelajaran 2017/2018, Jurnal Serunai Matematika, vo. 11(2), 2019.

Harleni S., dan Susilawati E., Efektivitas Penggunaan Model Problem Based Learning Terhadap Kemampuan Pemecahan Masalah Program Linier Dengan Memanfaatkan Software QM Pada Mahasiswa STKIP Budidaya Binjai, Jurnal Serunai Ilmu Pendidikan vol. 3(2), 2018.

\section{Meidawati Y., Pengaruh Pendekatan Pembelajaran Inkuiri Terbimbing Terhadap Peningkatan Kemampuan Pemecahan Masalah Matematika Siswa}

SMP, Jurnal Pendidikan dan Kegurunan, vol. 1(2), Tanggamus, 2014.

Miftachudin, Budiyono, Riyadi. Efektivitas Model Pembelajaran Two Stay Two Stray Dengan Tutor Sebaya Dalam Pembelajaran Matematika Pada Materi Bangun Datar Ditinjau Dari Kecerdasan Majemuk Peseta Didik Kelas VII SMP Negeri Di Kebumen Tahun Pelajaran 2013/2014, Jurnal Elektronik Pmbelajaran Matematika, Kebumen, 2015.

Purwosusilo, Peningkatan Kemampuan Pemahaman Dan Pemecahan Masalah Matematika Siswa SMK Melalu Strategi Pembelajaran REACT, Jurnal Pendidikan dan Keguruan, Jakarta, vol.1(2), 2014.

Susanto A., Teori Belajar dan Pembelajaran di Sekolah Dasar, PT Fajar Interpratama Mandiri, Jakarta, 2013. 